\title{
Experimental migration of knickpoints: influence of style of base-level fall and bed lithology
}

\author{
J.-L. Grimaud ${ }^{1,2}$, C. Paola ${ }^{1,2}$, and V. Voller ${ }^{1,3}$ \\ ${ }^{1}$ St. Anthony Falls Laboratory, University of Minnesota, 2 Third Avenue SE, Minneapolis, MN 55414, USA \\ ${ }^{2}$ Department of Earth Sciences, University of Minnesota, Minneapolis, MN 55414, USA \\ ${ }^{3}$ Department of Civil, Environmental, and Geo- Engineering, University of Minnesota, Minneapolis, USA
}

Correspondence to: J.-L. Grimaud (jgrimaud@umn.edu)

Received: 4 August 2015 - Published in Earth Surf. Dynam. Discuss.: 25 August 2015

Revised: 4 December 2015 - Accepted: 10 December 2015 - Published: 15 January 2016

\begin{abstract}
Knickpoints are fascinating and common geomorphic features whose dynamics influence the development of landscapes and source-to-sink systems - in particular the upstream propagation of erosion. Here, we study river profiles and associated knickpoints experimentally in a microflume filled with a cohesive substrate made of silica, water and kaolinite. We focus on the effect on knickpoint dynamics of varying the distribution of base-level fall (rate, increment, and period) and substrate strength, i.e., kaolinite content. Such simple cases are directly comparable to both bedrock and alluvial river systems. Under a constant rate of base-level fall, knickpoints of similar shape are periodically generated, highlighting self-organized dynamics in which steady forcing leads to multiple knickpoint events. Temporary shielding of the bed by alluvium controls the spacing between these unit knickpoints. Shielding is, however, not effective when base-level drops exceed alluvium thickness. While the base-level fall rate controls the overall slope of experiments, it is not instrumental in dictating the major characteristics of unit knickpoints. Instead the velocity, face slope and associated plunge pool depth of these knickpoints are all strongly influenced by lithology. The period between knickpoints is set by both alluvium thickness and base-level fall rate, allowing use of knickpoint spacing along rivers as an indicator of base-level fall rate.
\end{abstract}

\section{Introduction}

The retreat of knickpoints, i.e., localized steps in the river profile, is a common process in erosion systems. Knickpoints are created in response to an erosional perturbation and propagate information upstream into the landscape as opposed to the downstream transport of sediments fed from hillslopes (Whipple, 2004; Bishop, 2007; Allen, 2008). They are usually triggered by relative fall of the river base level, whether by uplift of the river bed or drop of the base level to which the river profile adjusts (e.g., a lake, a dam, a fault offset or the sea level). Knickpoints distributed within a landscape can thus be thought of as key signal carriers of external forcing at play in the sediment routing system.

Through use of physical experiments, base-level falls can successfully produce knickpoints over both alluvial/noncohesive or bedrock/cohesive substrates (for example: Brush and Wolman, 1960; Holland and Pickup, 1976; Begin et al., 1981; Gardner, 1983; Bennett et al., 2000; Frankel et al., 2007; Cantelli and Muto, 2014). Under supercritical flow conditions, the shape of the knickpoints is well preserved (Bennett et al., 2000; Cantelli and Muto, 2014). In some cases, upstream-migrating steps occur as a train of closely spaced knickpoints bounded by hydraulic jumps, termed "cyclic steps" by Parker (1996; Fig. 1). One might directly associate the presence of single knickpoints or trains of cyclic steps along a river with an ongoing or past external change, e.g., a relative base-level fall triggered by climate change or tectonics. However, knickpoints may also form in response to the reduction of sediment discharge along the river or can even be autogenic, arising from natural variability within a drainage basin (Hasbergen and Paola, 2000). Furthermore, dissipation is commonly observed as knickpoint retreat, and so the height of a knickpoint face does not neces- 


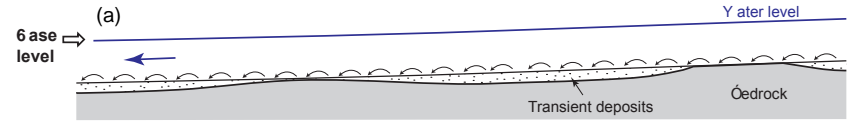

(b)

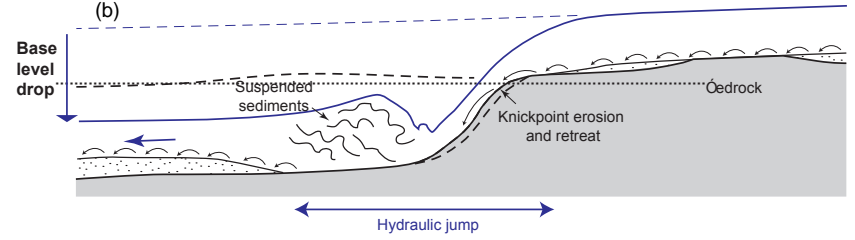

(c)

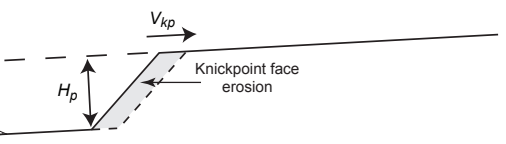

Figure 1. Schematic longitudinal section of a river bed before (a) and during (b) the propagation of a knickpoint triggered by relative base-level fall. Blue arrows represent flow direction and black arrows the motion of the bedload. The black and blue dashed lines respectively represent the bedrock and water levels before knickpoint propagation. (c) Idealized representation of a knickpoint characterized by its velocity, $V_{\mathrm{kp}}$, and the depth of associated plunge pool, $H_{\mathrm{p}}$.

sarily reflect the initial base-level fall (Parker, 1977; Gardner, 1983; Crosby and Whipple, 2006; Whipple, 2004; Bishop et al., 2005). Overall, there is still much to be worked out about the specifics of how knickpoints encode and carry erosional information.

Additionally, lithologic controls over river profiles and their knickpoints have long been recognized (Hack, 1957; Bishop et al., 1985; Miller, 1991; Pederson and Tressler, 2012). In recent field examples, Cook et al. (2013) measured lower rates of knickpoint retreat above more resistant rock, while Grimaud et al. (2014) documented the persistence of lithogenic knickzones (e.g., > $30 \mathrm{~km}$ long steeper reaches) at continental scale. Finally, Sklar and Dietrich $(2001,2004)$ highlighted bed lithology, i.e., variations in bedrock strength or alluvium thickness, as a major limiting factor of river abrasion capacity, through, for example, boulder armoring (Seidl at al., 1994), and therefore a control over the response timescale of the sediment routing system (see also Gasparini et al., 2006).

In this study, we investigate experimentally the effect of bed lithology and uplift style on knickpoint evolution. The experiments provide simple cases of 1-D evolution that are relevant for comparison with individual river segments. The results highlight the strong effect of bedrock lithology on knickpoint characteristics and show how incision and knickpoint propagation are influenced by transient deposits along streams. They also show a form of self-organization in which multiple small base-level steps may be required to produce a single knickpoint. This points to a new form of knickpoint self-organization that controls the relative rate at which knickpoints are generated as a function of the rate and mag-

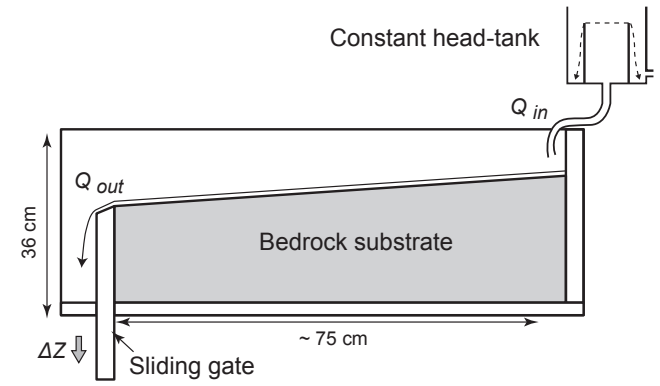

Figure 2. Experimental setup. Base-level fall, of rate $U$, is produced by lowering the sliding gate. $Q_{\text {in }}$ is the water discharge introduced the flume using a constant head tank. $Q_{\text {out }}$ is the water discharge measured at the outlet of the flume. Because of absorption by the substrate, $Q_{\text {in }}\left(1250 \mathrm{~mL} \mathrm{~min}^{-1}\right)$ is superior to $Q_{\text {out }}$ in every experiment (see Table 1$)$.

nitude of base-level fall. The results suggest that knickpoint spacing, though not vertical magnitude alone, is an indicator of base-level fall rate.

\section{Experimental setup}

\subsection{Flume design and experiment sets}

We carried out experiments on river incision at the St. Anthony Falls Laboratory, University of Minnesota, Minneapolis. To minimize planform complications such as bars, we constructed a small, narrow flume to test the impact of baselevel fall style and bed lithology on stream erosion. The flume is $1.9 \mathrm{~cm}$ wide, about $100 \mathrm{~cm}$ long and $36 \mathrm{~cm}$ high (Fig. 2). We supplied a constant water discharge $\left(Q_{\text {in }}=\right.$ $1250 \mathrm{~mL} \mathrm{~h}^{-1}$ ) over a cohesive substrate, which eroded and formed a profile. The substrate is very similar to the one used by Hasbargen and Paola (2000). It is composed of silica sand $\left(\right.$ density $\left.=2.65 ; d_{50}=90 \mu \mathrm{m}\right)$, kaolinite (density $\left.=2.63 ; d_{50}<4 \mu \mathrm{m}\right)$ and water. The composition of the substrate controls its erodibility, one of the key variables we wished to study. This substrate is placed wet into the flume and its top surface flattened as much as possible. The experiment starts immediately. Water introduction causes the slow erosion of the first upstream $10 \mathrm{~cm}$ of the flume that provides a constant minimum bedload $\left(q_{\mathrm{s}} \sim 3 \mathrm{~g} \mathrm{~min}^{-1}\right)$. This bedload acts as an abrasion tool throughout the experiments (Sklar and Dietrich, 2004; Fig. 1). The stream is perturbed by lowering the downstream end of the flume using a sliding gate (Fig. 2). In response to this perturbation, knickpoints develop and retreat upstream (Figs. 3 and 4).

We carried out several experimental sets. Experiment 1 is the base case to which other experiments can be compared (rate of base-level fall, $U=2.5 \mathrm{~cm} \mathrm{~h}^{-1}$; incremental baselevel drops, $\Delta Z=0.25 \mathrm{~cm}$ and kaolinite fraction $f_{\mathrm{k}}=1 \%$ by weight when dry; see Table 1). First, we tested base-level fall scenarios. During experiments 2, 3, 5 and 6, $U$ was set 

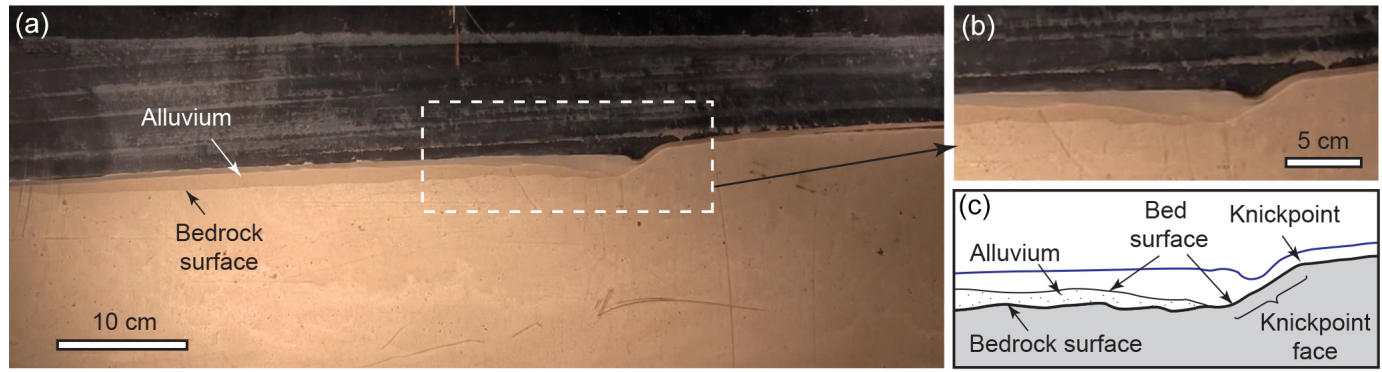

Figure 3. Illustration of a knickpoint observed along the flume during experiment 10. (a) Overall view of the profile and (b, c) details of the knickpoint. Note the white color of the water due to suspended sediments.

Table 1. Summary of the main characteristics for each experiments. $\tau_{\text {eq }}$ represents the equilibrium shear stress. NA stands for no acquisition.

\begin{tabular}{|c|c|c|c|c|c|c|c|c|c|c|}
\hline Experiment & 1 & 2 & 3 & 5 & 6 & 7 & 8 & 9 & 10 & 11 \\
\hline Base-level fall rate, $U\left(\mathrm{~cm} \mathrm{~h}^{-1}\right)$ & 2.5 & 5 & 1.25 & 0.5 & 50 & 2.5 & 5 & 2.5 & 2.5 & 2.5 \\
\hline Base-level drop, $\Delta Z(\mathrm{~cm})$ & 0.25 & 0.25 & 0.25 & 0.25 & 0.25 & 2.5 & 2.5 & 0.25 & 0.25 & 0.25 \\
\hline Kaolinite fraction, $f_{\mathrm{k}}(\%)$ & 1 & 1 & 1 & 1 & 1 & 1 & 1 & 0 & 2 & 5 \\
\hline Discharge, $Q_{\text {out }}\left(\mathrm{mL} \mathrm{min}^{-1}\right)$ & 800 & 770 & 730 & 900 & 820 & 895 & 890 & 970 & 900 & 755 \\
\hline Flow depth, $h(\mathrm{~mm})$ & 2.5 & 2 & 2.75 & 3.25 & 1.1 & 2 & 2.5 & 2.5 & 1.75 & 2 \\
\hline Flow velocity, $V_{f}\left(\mathrm{~m} \mathrm{~s}^{-1}\right)$ & 0.28 & 0.34 & 0.23 & 0.24 & 0.65 & 0.39 & 0.31 & 0.34 & 0.45 & 0.33 \\
\hline Froude number & 2.10 & 2.41 & 1.31 & 1.22 & 3.95 & 2.8 & 1.99 & 2.82 & 3.82 & 2.36 \\
\hline Reynolds number & 2222 & 2232 & 1986 & 2353 & 2579 & 2594 & 2472 & 2694 & 2667 & 2188 \\
\hline Equilibrium slope & 0.061 & 0.077 & 0.051 & 0.037 & 0.15 & NA & NA & 0.054 & 0.066 & NA \\
\hline$\tau_{\mathrm{eq}}(\mathrm{Pa})$ & $1.18 \pm 0.14$ & $1.28 \pm 0.17$ & $1.11 \pm 0.11$ & $0.88 \pm 0.08$ & $1.9 \pm 0.33$ & NA & NA & $0.91 \pm 0.12$ & NA & NA \\
\hline $\mathrm{KP}$ velocity, $V_{\mathrm{kp}}\left(\mathrm{cm} \mathrm{min}^{-1}\right)$ & 8.2 & 8.1 & 6.8 & 8.8 & 11.6 & 9.8 & 11.8 & 17 & 7 & 0.7 \\
\hline $\mathrm{KP}$ frequency $(\mathrm{Hz})$ & 0.0006 & 0.0008 & 0.0003 & 0.0001 & 0.0046 & 0.0003 & 0.0006 & 0.0009 & 0.0004 & 0.0003 \\
\hline Period between KP, $\Delta t$ (min) & 28.8 & 20.0 & 48.0 & 118.0 & 3.6 & 60.0 & 30.0 & 18.4 & 43.6 & 48.6 \\
\hline Plunge pool depth, $H_{\mathrm{p}}(\mathrm{cm})$ & 1.23 & 1.19 & 0.97 & 1.13 & 1.31 & NA & NA & 1.25 & 1.82 & 3 \\
\hline & Base case & \multicolumn{4}{|c|}{ Base-level fall variations } & Base-le & riations & \multicolumn{3}{|c|}{ Substrate variations } \\
\hline
\end{tabular}

to $5,1.25,0.5$ and $50 \mathrm{~cm} \mathrm{~h}^{-1}$, respectively, while $\Delta Z$ and $f_{\mathrm{k}}$ were kept similar to experiment 1 . In other words, the base level was dropped $0.25 \mathrm{~cm}$ every $30 \mathrm{~min}$ to get a $0.5 \mathrm{~cm} \mathrm{~h}^{-1}$ rate and every $3 \mathrm{~min}$ to get a $5 \mathrm{~cm} \mathrm{~h}^{-1}$ rate. During experiment $7, U$ and $f_{\mathrm{k}}$ were similar to experiment $1\left(2.5 \mathrm{~cm} \mathrm{~h}^{-1}\right.$ and $1 \%$ ) but $\Delta Z$ was changed to $2.5 \mathrm{~cm}$ (Table 1). To keep the same base-level fall rate, the base level was then dropped $2.5 \mathrm{~cm}$ every $60 \mathrm{~min}$. Similarly, the base level was dropped $2.5 \mathrm{~cm}$ every $30 \mathrm{~min}$ in experiment 8 so that it could be compared to experiment 2 . Finally, different substrate lithologies were tested. The kaolinite fraction, $f_{\mathrm{k}}$, was changed to 0,2 and $5 \%$ during experiments 9,10 and 11 , respectively, while $U$ and $\Delta Z$ were kept similar to experiment 1 (Table 1).

\subsection{Measurements and uncertainties}

We define the knickpoint as the point where a river steepens, whereas the knickpoint face corresponds to the steep reach starting at this knickpoint and ending at the bottom of the plunge pool (e.g., Gardner, 1983; Figs. 1c and 3c). We measured geometries of the profile and knickpoints using a camera placed along the flume. Pictures were extracted every 24 $30 \mathrm{~s}$ and corrected for lens distortion and vertical stretching in order to measure the overall experimental slope, knickpoint face slope, and knickpoint face length. Water depth was measured using a point gauge, while water discharge (e.g., $Q_{\text {out }}$; Fig. 2) was measured throughout experiments using a graduated cylinder. The hydraulic parameters of each experiment were calculated using these measures (Table 1). Reynolds numbers fall between 1900 and 2700, while Froude numbers are all above 1 , indicating that the flow regime is respectively transitional to turbulent and supercritical (Table 1).

On the extracted pictures, no vertical or horizontal position could be accurately measured below a two-pixel resolution, i.e., $1.33 \mathrm{~mm}$. These vertical and horizontal errors were combined in a simple propagation formula based on variance $(\mathrm{Ku}, 1966)$ to assess uncertainties in the metrics used in this study. A test evaluation calculated for experiment 3 showed that variance of the overall experiment's slope was around 0.0017 (i.e., $\sim 5 \%$ equilibrium slope of experiment 3 ) and knickpoint velocity variance was about $2 \mathrm{~mm} \mathrm{~h}^{-1}$ (i.e., $\sim 3 \%$ of average knickpoint velocity for experiment 3 ). Therefore, both overall slope and knickpoint velocity do not vary significantly due to measurement. On the other hand, measures of the variance of knickpoint face length and slope have greater uncertainties. For instance, when the overall experiment is steep (e.g., experiment 6; Table 1), the transition to the knickpoint face along the profile is not sharp and a horizontal measurement error up to $15 \mathrm{~mm}$ is possible, es- 

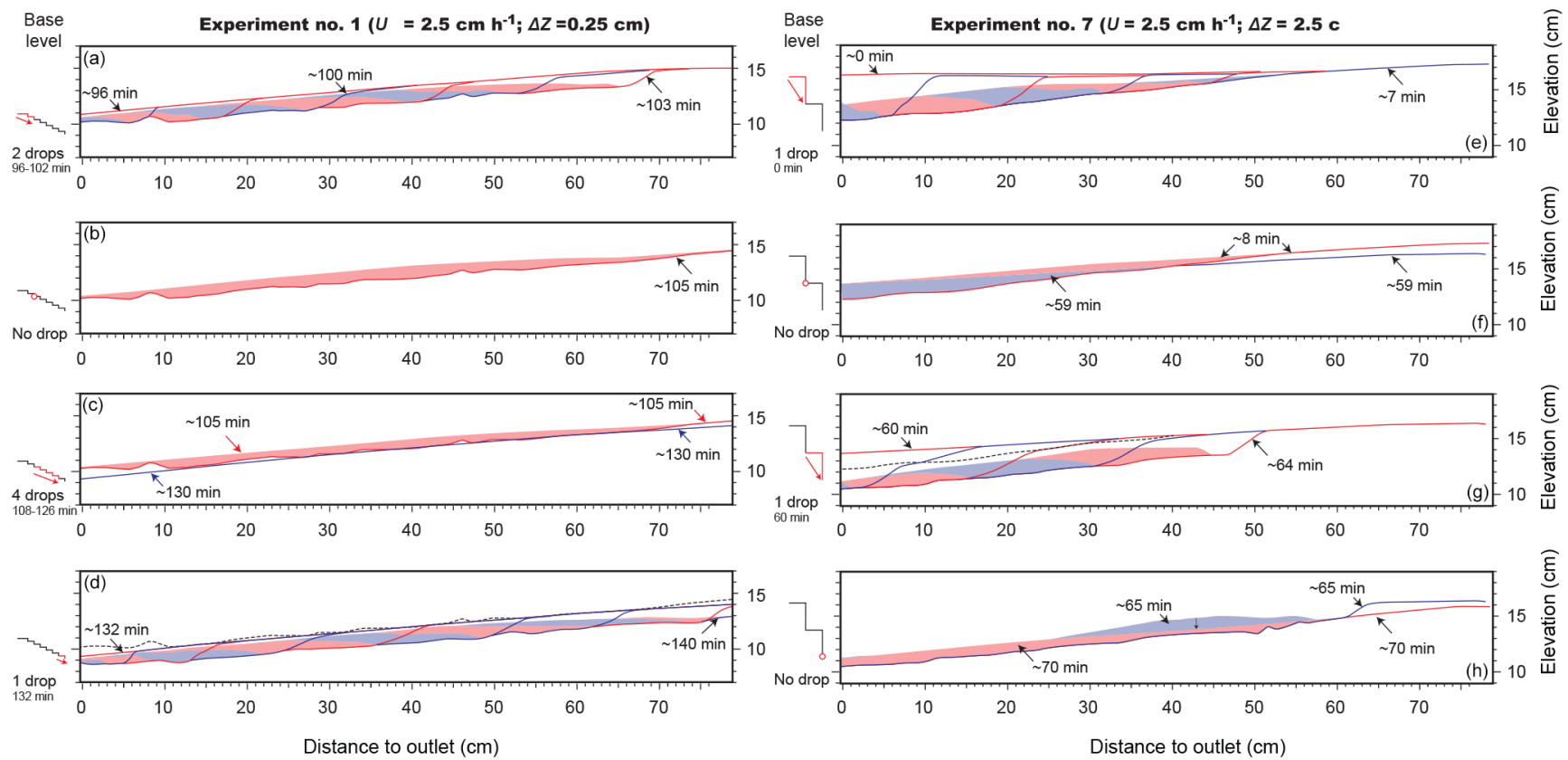

Figure 4. Evolution of two experiments with the same average rate of base-level fall $\left(U=2.5 \mathrm{~cm} \mathrm{~h}^{-1}\right)$, but different incremental base-level drops, $\Delta Z$. (a)-(d) For experiment $1(\Delta Z=0.25 \mathrm{~cm})$, a knickpoint is propagating in between 96 and 103 min (a), leaving a alluvial layer (b) that will be progressively removed as the base level of the experiment is lowered between 105 and 130 min (c). A new knickpoint starts retreating in between 132 and $140 \mathrm{~min}$ once the alluvium has disappeared (d). (e)-(h) For experiment $7(\Delta Z=2.5 \mathrm{~cm})$, a new knickpoint is generated each time the base level is dropped (i.e., in between 0 and $8 \mathrm{~min}$ (e) and in between 60 and $69 \mathrm{~min}$ (g)). In between these drops, the profile's slope is lowered by overall diffusion ((f) and (h); see also Fig. 7b). Blue and red colored lines correspond to the successive elevation of the bedrock surface, while the light-blue and red area corresponds to the alluvium. The position of the base level is tracked on the left side of each frame. Vertical exaggeration is 1.375 .

pecially approaching the plunge pool (Figs. 1 and 3). The resulting knickpoint face slope variance, calculated for experiment 6 assuming a vertical error of $1.33 \mathrm{~mm}$, is about $3^{\circ}$. Therefore, two knickpoint face slopes would be significantly different only if their difference is greater than $3^{\circ}$. Plunge pool depth was calculated from knickpoint face slope and knickpoint face length and corrected for the overall slope of experiments (e.g., Fig. 1c). Error on flow depth, $h$, is approximately $0.25 \mathrm{~mm}$. This together with uncertainty in slope allowed us to estimate the uncertainty in the shear stress, $\tau_{\mathrm{eq}}$, shown in Table 1.

\section{Results}

\subsection{Knickpoint generation and periodicity}

We observe threshold behavior in the total base-level drop needed to generate a knickpoint. In the case of $\Delta Z=0.25 \mathrm{~cm}$, two to eight drops are needed to generate the first knickpoint. A small initial knickpoint retreats about 30 average stream depths $(7 \mathrm{~cm})$ upstream and then remains stationary for 1-2 min. During this period, the plunge pool at the foot of the knickpoint face deepens and a hydraulic jump forms. This phase is characterized by over-erosion, i.e., the bottom of the plunge pool becomes lower than the newly imposed base level. After the plunge pool reaches a depth of $1-3 \mathrm{~cm}$ (Fig. 4), the knickpoint begins to retreat at constant speed. In the case of $\Delta Z=2.5 \mathrm{~cm}$, a knickpoint is generated for each base-level drop and retreats uniformly (Fig. 4e). During knickpoint retreat, the sand-kaolinite substrate is eroded and the kaolinite and sand separate. The kaolinite is transported out of the system in suspension, while the sand is deposited downstream of the knickpoint to form a layer (alluvium; Figs. 3, 4a and e). Once a knickpoint reaches the upstream end of the flume, the alluvium remains along the profile (Fig. 4b and f). This layer is slowly removed as the river profile is smoothly lowered by overall diffusion over both the alluvium and the bedrock substrate (Fig. 4b, c and f). This indicates that the sediment layer acts as a shield that prevents erosion of the bedrock substrate (Sklar and Dietrich, 2004): no significant knickpoint-hydraulic jump couple is observed during the diffusion phase. Only close observation of the bed indicates that smaller knickpoints (i.e., shallower than the stream depth) develop and propagate while the bed is shielded by sediment.

Depending on the magnitude of base-level drop, $\Delta Z$, the period between knickpoints is not constant. In the case of $\Delta Z=2.5 \mathrm{~cm}$, and after the alluvium is in place, the baselevel drop is greater than the alluvium thickness, allowing 


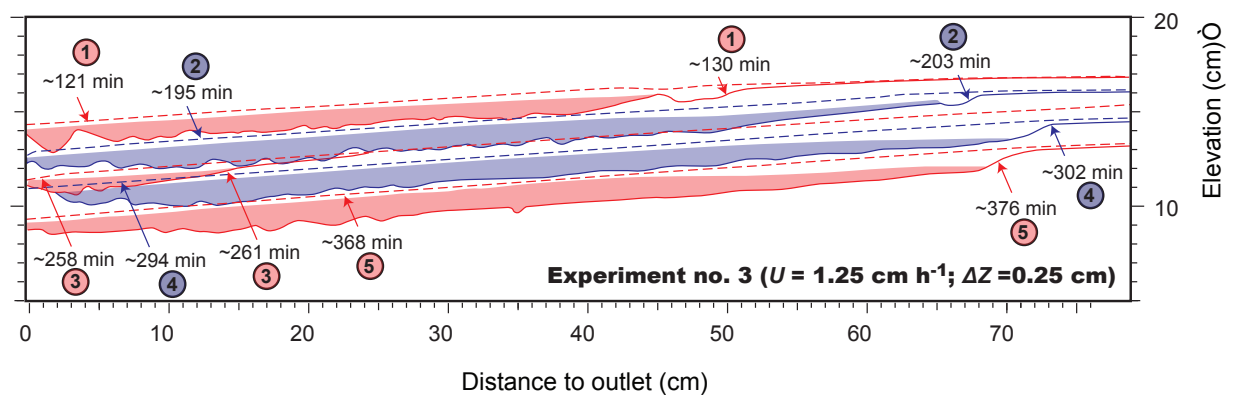

Figure 5. Evolution of the entire experiment $3\left(U=1.25 \mathrm{~cm} \mathrm{~h}^{-1} ; \Delta Z=0.25 \mathrm{~cm}\right)$ showing alluvium thickness deposited in response to the retreat of knickpoints (enumerated from 1 to 5). Blue and red colored lines correspond to the elevation of the bedrock surface at the end of the knickpoint retreat, while the blue and red colored dashed lines correspond to the elevation of the bedrock before knickpoint propagation. Light-blue and red areas represent the alluvium. A new knickpoint is generated only when the alluvium is removed from the profile. Note the abortion of knickpoint 3 after 3 min of retreat (see text for explanations). Vertical exaggeration is 1.375.

each drop to form a knickpoint (Fig. 4e and g). The face of a new knickpoint is irregular, i.e., its slope changes at the transition between the bedrock and the remaining bed sediments (Fig. 4g). In that case, the average period between knickpoints corresponds to the time between each base-level drop (e.g., $60 \mathrm{~min}$ for experiment 7 and $30 \mathrm{~min}$ for experiment 8; Table 1). In the case of $\Delta Z=0.25 \mathrm{~cm}$, the alluvium has to be removed before a new knickpoint can be generated and retreat (Fig. 4c and d). In this regime, the average period between knickpoints is therefore a function of the alluvium thickness to be eroded in the flume (Table 1). A detailed sequence is shown in Fig. 5 for experiment 3. Overall, the knickpoint period is about $70 \mathrm{~min}$ for most of this experiment (e.g., the time needed to produce a base-level fall equal to the alluvium thickness, $1.25 \mathrm{~cm}$ ). However, the geometry of the bedrock surface is irregular and hence the sediment thickness too. Accordingly, the third knickpoint generated disappears upon reaching sediment deposits in the flume (Fig. 5). First, the alluvial layer is rapidly removed along the upper section of the knickpoint face. This produces a two-step knickpoint face that is progressively smoothed. This smoothing disturbs the flow: the hydraulic jump cannot be maintained and the knickpoint fades. As a consequence, thinner alluvium is left along the flume and the next (fourth) knickpoint starts after only $33 \mathrm{~min}$ (Fig. 5). This indicates that transient alluvial deposits can disturb the flow and temporarily prevent knickpoint formation or propagation.

\subsection{Equilibrium slope and timescales}

Figure 6 shows the overall evolution of experimental profiles as a function of base-level fall rate $(\Delta Z=0.25 \mathrm{~cm})$. These profiles correspond to the bed surface and not to the bedrock surface. Each experiment starts with a nearly flat profile whose slope increases (dashed lines; Fig. 6) until stabilization (plain lines). As base-level fall rate increases, profiles become steeper: Fig. 7a shows that profile slopes increase proportionally to the rate of base-level fall. Each ex- periment reaches a quasi-equilibrium slope that is proportional to the rate of base-level fall applied. Knickpoint frequency also increases as a function of base-level fall rate and more knickpoints are captured along the profiles from Fig. 6a to e (see also Table 1). This configuration is enhanced for $U=50 \mathrm{~cm} \mathrm{~h}^{-1}$ (experiment 6), where several knickpoints can retreat simultaneously. In this configuration, and similar to experiments 7 and 8 , knickpoints are propagating even though sediments are preserved along the profile. However, the downstream reach (first $10 \mathrm{~cm}$ of the flume) must be free of alluvium in order for a knickpoint to be generated.

Figure $7 \mathrm{~b}$ shows the evolution of slope for experiments 7 and 8 , which have base-level fall rate similar to experiments 1 and 2, respectively, but a $\Delta Z 10$ times higher (e.g., $2.5 \mathrm{~cm}$ ). Experiment $5\left(U=0.5 \mathrm{~cm} \mathrm{~h}^{-1} ; \Delta Z=0.25 \mathrm{~cm}\right)$ is shown for comparison. After $100 \mathrm{~min}$, experiments 7 and 8 have a slope that is high but lower than experiments 1 and 2, respectively. Furthermore, the profiles of the former decrease and converge towards a low equilibrium slope, which is close to the equilibrium slope in experiment 5 . In all these experiments (5, 7 and 8), a common characteristic is the low frequency of base-level drops and the conversely long period in between these drops ( $\geq 30 \mathrm{~min}$ ). This suggests that these experiments are more affected by smooth profile readjustment by diffusion during quiescent periods and less by knickpoint retreat.

An analysis of the stream slope according to lithology is shown in Fig. 7c. Lithology or substrate strength is represented as the kaolinite percentage within the substrate, $f_{\mathrm{k}}$. For similar uplift rates, the experiment without kaolinite has a lower equilibrium slope than the experiment with $1 \%$ kaolinite. However, the equilibrium slopes of experiments 1 and 10 (with respectively 1 and $2 \%$ of kaolinite) are similar. Therefore, despite their different bedrock strengths, these two cases are at equilibrium with the alluvium and not the substrate. Indeed, shear stress calculated at the equilibrium slope for experiments 1, 2, 3, 5 and 6 goes as the base-level fall rate (Fig. 7d). A tentative exponential fit suggests that the shear stress for $U=0 \mathrm{~cm} \mathrm{~h}^{-1}(0.91 \pm 0.5)$ 

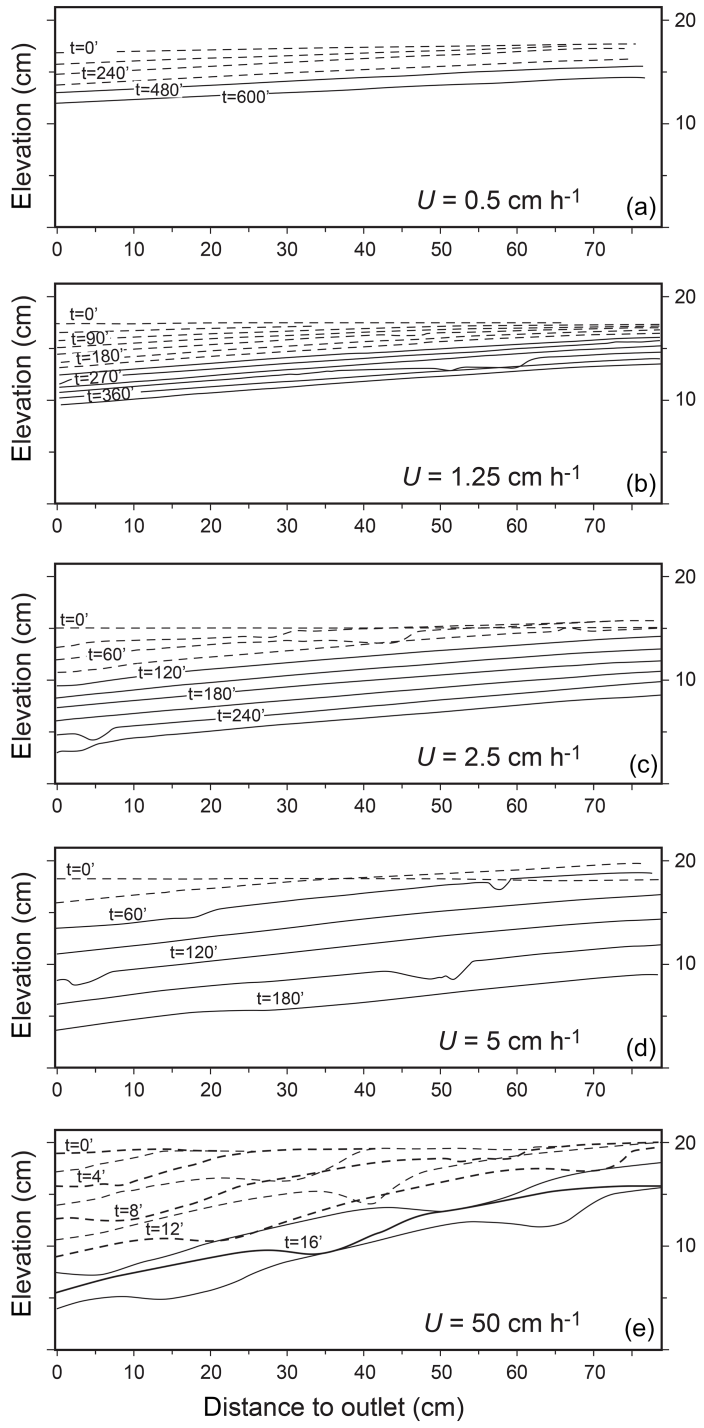

Figure 6. Evolution of the profile's bed surface elevation as a function of the base-level fall rate (see also Fig. 7a). The bed surface can be either the bedrock or the alluvium surface. Note that the amount of knickpoint increases with base-level fall rate.

would be above the shear stress of motion (i.e., $\sim 0.13 \mathrm{~Pa}$ for $d_{50}=0.1 \mathrm{~mm}$; Julien, 1998) and that the evolution of these slopes is controlled by alluvium removal. The comparison between Fig. $7 \mathrm{a}$ and $\mathrm{c}$ further suggests that the overall equilibrium slope varies more strongly with base-level fall rate than lithology. When $f_{\mathrm{k}}=5 \%$, no equilibrium is attained and the quasi-equilibrium state has a strong sinusoidal shape (Fig. 7c): a maximum value is reached about every $100 \mathrm{~min}$. Given a typical knickpoint velocity of about $0.7 \mathrm{~cm} \mathrm{~min}^{-1}$ (experiment 11; Table 1) and the flume experimental section length $75 \mathrm{~cm}, 100 \mathrm{~min}$ corresponds to the time required for a knickpoint to reach the upstream part of the flume. This indicates that low knickpoint velocity lengthens the readjust- ment timescale of the overall profile as higher relief can be maintained until knickpoints pass through the system.

\subsection{Controls on knickpoint characteristics}

In Fig. 8, we investigate knickpoint properties in relation to $U$ and $f_{\mathrm{k}}$. Figure 8a to $\mathrm{d}$ show that the knickpoint face slope and plunge pool depth increase linearly as a function of $f_{\mathrm{k}}$ (Fig. 8e). These characteristics do not vary significantly as a function of the uplift rate: only a slight increase in knickpoint slope and plunge pool depth are suggested as functions of $U$ (Fig. 8f). This shows that these knickpoint properties are primary controlled by lithology. The same statement applies for knickpoint retreat velocity: while variations in $U$ from 0.5 to $50 \mathrm{~cm} \mathrm{~h}^{-1}$ do not show a statistically significant increase in knickpoint velocity (Fig. 8h), an increase from 0 to $5 \%$ kaolinite is responsible for a knickpoint velocity decrease from 17 to $0.7 \mathrm{~cm} \mathrm{~h}^{-1}$ (Fig. $8 \mathrm{~g}$ ). The effect of kaolinite fraction on knickpoint velocity can be fit by an equation of the form

$V_{\mathrm{kp}}=V_{\mathrm{max}} \mathrm{e}^{-\alpha \cdot f_{\mathrm{k}}}$,

where $V_{\max }$ is the maximum velocity attained over sand (e.g., $f_{k}=0$ ) and $\alpha$ is a dimensionless fitting parameter. Less dramatically, the increase in $\Delta Z$ from 0.25 to $2.5 \mathrm{~cm}$ increases knickpoint retreat velocity by $20 \%$ (i.e., comparison between experiments 1 and 7 and experiments 2 and 8 in Table 1). This indicates that knickpoint velocity may still be partially influenced by base-level fall velocity. Finally, while Bennett et al. (2000) showed that plunge pool depth increases with water discharge, our results suggest that this depth also goes with the kaolinite fraction (Fig. 8e):

$H_{\mathrm{p}} \sim f_{\mathrm{k}}$.

\section{Discussion}

\subsection{Knickpoint self-organization}

The experiments presented in this study were carried out in a small 1-D flume with very simple conditions compared to natural systems: constant discharge, constant lithology per experiment, no interfluve processes (debris-flow, pedimentation, etc.) and no possibility for the channel to widen (although channel narrowing has been observed in experiment 11; see caption of Fig. 8). The first and most striking result of this study is that, even under these simple conditions, knickpoint dynamics remain surprisingly complex and exhibit strong autogenic (self-organized) variability mediated by alluvium dynamics and associated bed sheltering, and by the erosional threshold for the bedrock substrate. Indeed, the interaction between bed lithology and base-level fall style (i.e., overall rate and distribution of vertical offsets) provides a variety of configurations that strongly affects the evolution of river profiles. 

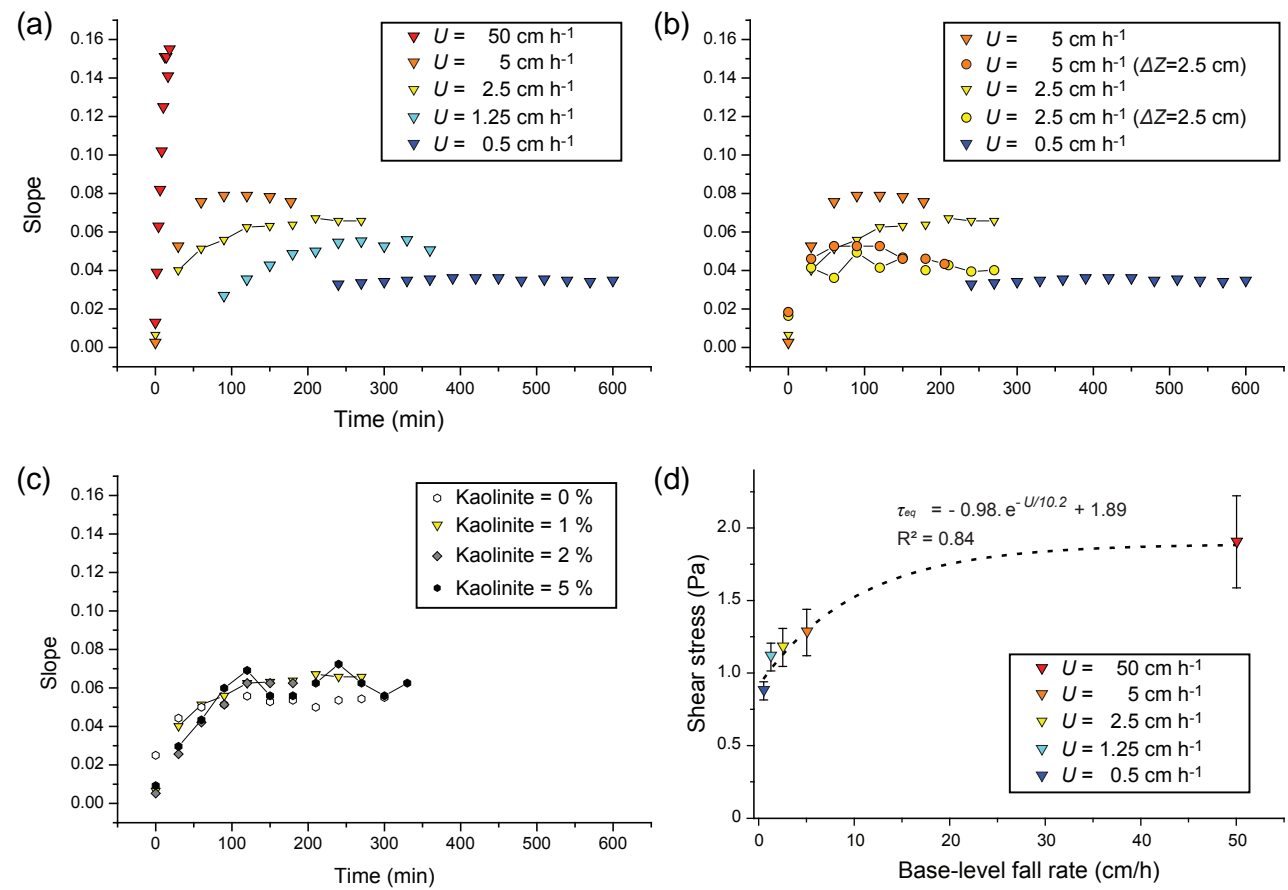

Figure 7. (a)-(c) Evolution of mean slope of the experiments with time for different sets of experiments. (a) Evolution with base-level fall rate. (b) Evolution with different base-level fall styles. For experiments 5, 7 and 8 (respectively represented by the blue triangles, yellow circles and orange circles), the minimum time between each base-level drop is $30 \mathrm{~min}$. (d) Evolution of the equilibrium shear stress as a function of their base-level fall rate for experiments where $\Delta Z=0.25 \mathrm{~cm}$. Exponential fit is shown with a dashed line.

As observed in other geomorphic physical experiments (Paola et al., 2009), the transient storage and release of sediments along the flume is responsible for self-organized dynamics that in the problem at hand delay knickpoint propagation in response to base-level fall (Figs. 4 and 5). This behavior is particularly observed when $\Delta Z$ is on the order of or lower than the flow depth (i.e., $0.25 \mathrm{~cm}$; Table 1). As described for alluvial-bedrock rivers (Sklar and Dietrich, 2004), the alluvium acts as a shield for incision by knickpoint retreat and the river profile is characterized by overall diffusive removal of the sediments until it becomes too thin to shield the bedrock. However, when the incremental or cumulated base-level fall is large enough, i.e., larger than the sediment thickness, the effect of transient alluvium is less prominent, suggesting that high-magnitude external forcing is still likely to produce knickpoints (Fig. 4; Jerolmack and Paola, 2010). Hence, one directly testable outcome of this work is that offset can generate a knickpoint only when its magnitude exceeds the thickness of any alluvial layer present on the bed. The thickness of the alluvial layer sets an offset threshold for knickpoint generation. In an environment in which uplift is generated by earthquakes, we expect (1) knickpoint propagation in response to fault displacement if the offset exceeds the thickness of piedmont/alluvial deposits but (2) overall diffusion (no knickpoint) for offset is lower than the alluvial thickness. The latter therefore points to the ability of alluvial covers to filter small-scale base-level variations that may not be recorded by knickpoint propagation.

While the rate of base-level fall (or uplift) primarily controls overall slope (Figs. 6, 7a and c; Bonnet and Crave, 2003), knickpoint characteristics are dominated by bedrock strength, which in the experiments increases with kaolinite content (Fig. 8). Earlier work has demonstrated that the critical shear stress of sand/clay mixtures increases with their clay content (Mitchener and Torfs, 1996). Hence, similar to field measurements (Cook et al., 2013), the velocity of knickpoint retreat is inversely proportional to substrate strength in our experiments. This militates against assuming that the retreat rate of knickpoints is constant over varying bedrock lithologies. Future studies investigating uplift history through inverse modeling should therefore integrate a lithological term (see Wilson et al., 2014) to simulate knickpoint or knickzone retreat rate.

Surprisingly, our 1-D experiments show that base-level variation, a key parameter studied in erosion /deposition systems, is not encoded by knickpoint height, i.e., $H_{\mathrm{p}}$. Instead, $H_{\mathrm{p}}$ mostly goes with water discharge and bedrock strength (Bennett et al., 2000; this study). Specifically, our experiments show that, for base-level fall created by offsets, the sum of the offsets must reach a threshold (> sediment thickness) to trigger a knickpoint. The experiments of Cantelli and Muto (2014) give insight into the complementary case: 

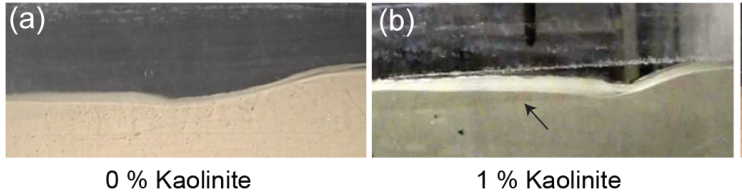

$1 \%$ Kaolinite

(e)

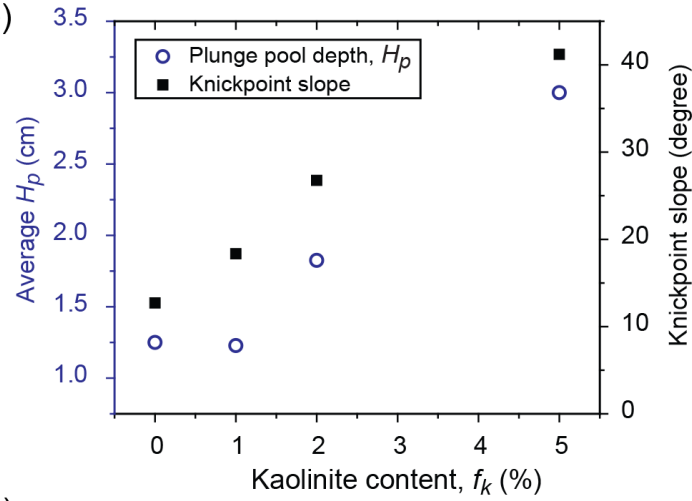

(g)

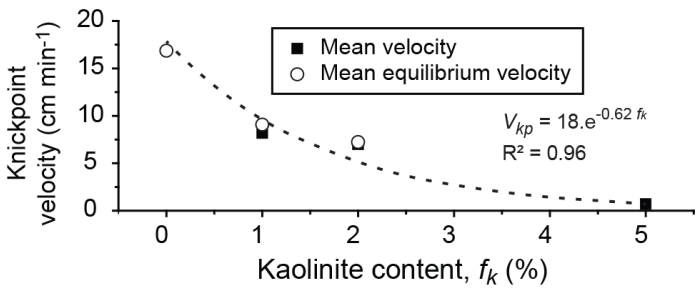

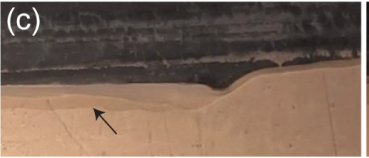

$2 \%$ Kaolinite

\% Kaolinite

(f)

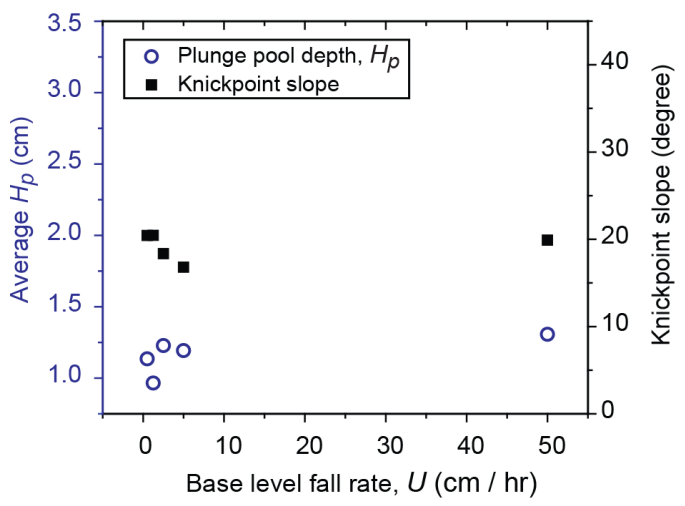

(h)

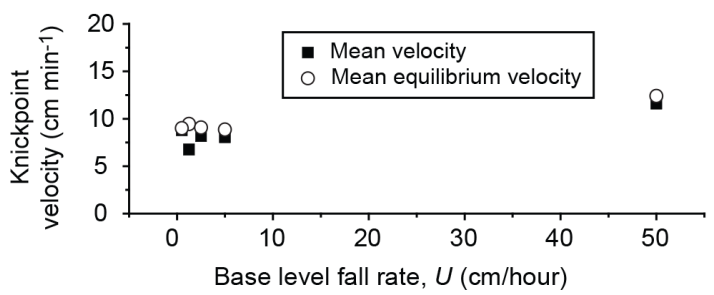

Figure 8. Knickpoint characteristics as a function of base-level fall rate and substrate. (a)-(d) Illustrations of the knickpoint shapes as a function of the kaolinite content $\left(f_{\mathrm{k}}\right)$ in the substrate. Note that the plunge pool depth could not be measured from photographs for experiment $11\left((\mathbf{d}) ; f_{\mathrm{k}}=5 \%\right)$ : the substrate was so cohesive that it stuck on the walls and the bottom of the plunge pool was not accessible. $H_{\mathrm{p}}$ was, however, estimated to be ca. $3 \mathrm{~cm}$ on the flume during experiment 11 . In this experiment, the geometry of the bed was more heterogeneous and the channel narrowed to incise the bedrock. The dashed line corresponds to the approximate bottom on the plunge pool. (e) Variations in knickpoint slope and plunge pool depth as a function of $f_{\mathrm{k}}$. (f) Variations in knickpoint slope and plunge pool depth as a function of the base-level fall rate, $U$. (g) Mean knickpoint retreat velocity shown as a function of $f_{\mathrm{k}}$. The exponential fit is represented with a dashed line. (h) Mean knickpoint retreat velocity shown as a function of $U$.

if the offset is too large, a series of knickpoints rather than just one is generated. Together, these findings suggest that, similar to drainage basins that tend to be regularly spaced in mountain belts (Hovius, 1996), knickpoints tend toward an optimal knickpoint shape - a kind of "unit knickpoint". This unit knickpoint is a function of water discharge and lithology (Eq. 2), and presumably could be strongly influenced by, for example, layering in the substrate (e.g., Holland and Pickup, 1976), which is not present in our experiments and those of Cantelli and Muto. To summarize, there is no one-toone correlation between knickpoints along river profiles and base-level events: one base-level drop can generate multiple knickpoints, but one knickpoint can also result from multiple events.

At this point, we are not able to predict theoretically the properties of unit knickpoints. Overall, plunge pool depth goes inversely with knickpoint velocity (Table 1), although there is more scatter when the lithology is constant and baselevel fall rate varies (e.g., experiments 2, 3, 5 and 6). This suggests that slow retreat of a knickpoint and associated plunge pool results in more vertical erosion of the bed by scouring and increases the plunge pool depth (see Stein and Julien, 1993). A second useful limit is the cyclic steps described by Parker (1996), which can be thought of as a train of linked unit knickpoints, and are what we observe in our experiments under rapid base-level fall (Fig. 6e). However, while Parker described these features as self-formed, the ones presented in this study are forced externally. The connection between individual knickpoints and trains of cyclic steps deserves further study; however, we note that in terms of local hydraulics and sediment motion, the knickpoints we generated function similarly to Parker's steps, despite being solitary except in the limiting case of rapid base-level fall. Hence, the geometry of cyclic steps may provide a constraint on that of a unit knickpoint and hence a means of predicting the characteristics of knickpoints generated by specific scenarios of base-level fall. Another limit is that unit knickpoints may not be generated or preserved in the case of catas- 
trophic base-level fall. This is suggested by the evolution of the Rhone Valley in response to the $1500 \mathrm{~m}$ drop associated with the salinity crisis in the Mediterranean Sea (Loget et al., 2006) and also in the case of a catastrophic drop simulated experimentally (A. Cantelli, personal communication, 2015).

\subsection{Analysis of knickpoint distribution}

The evolution of river bed and knickpoint retreat is commonly simulated numerically using a combined advectiondiffusion equation (Howard and Kerby, 1983; Rosenbloom and Anderson, 1994; Whipple and Tucker, 1999; see Bressan et al., 2014). In this study, advection is observed through knickpoint generation every 3-120 min (Table 1). As a comparison, the diffusion response timescale $T$ of the experiments can be approximated in the same way than alluvial systems, using the system (flume) length $L$ and width $W(\mathrm{~m})$, the sediment discharge $q_{\mathrm{s}}\left(\mathrm{m}^{3} \mathrm{~min}^{-1}\right)$, and the overall equilibrium slope $S$ (Métivier and Gaudemer, 1999; Allen, 2008).

$T=\frac{L^{2} W S}{q_{\mathrm{s}}}$

This timescale is $300-1400 \mathrm{~min}$, i.e., longer that the period in between knickpoints. This indicates that most experiments presented in this study are dominated by knickpoint advection (except experiments 5, 7 and 8; Sect. 3.2): despite their relatively fast migration, knickpoints are generated too often to allow the stream to entirely relax by diffusion.

Erosion of the bed is usually modulated by a threshold that must be surpassed in order for the river to erode (van der Beek and Bishop, 2003; Snyder et al., 2003; Sklar and Dietrich, 2004). However, many simulations of knickpoint retreat assume that each base-level drop can generate a new knickpoint and that the initial geometry of knickpoints is offset by the base-level drop. As pointed out before, this is not reasonable if knickpoints tend to a unit form, independent of the magnitude of base-level fall. Our analysis has shown that unit knickpoints are generated when the alluvium is removed from the river bed, i.e., every time the base level reaches the bottom of the plunge pool, $H_{\mathrm{p}}$ (Figs. 4 and 5). The period between knickpoints, $\Delta t$, can then be simply approximated as a function of the base-level fall rate:

$\Delta t=\frac{H_{\mathrm{p}}}{U}$.

This is supported by the comparison between knickpoint period measured from the experiments and estimated after Eq. (4) (e.g., for experiments 1, 2, 3, 5, 6, 9, 10 and 11; Fig. 9). Equation (4) can then be derived to estimate the spacing between knickpoints:

$\Delta x=\Delta t V_{\mathrm{kp}}=\frac{H_{\mathrm{p}}}{U} V_{\mathrm{kp}}$.

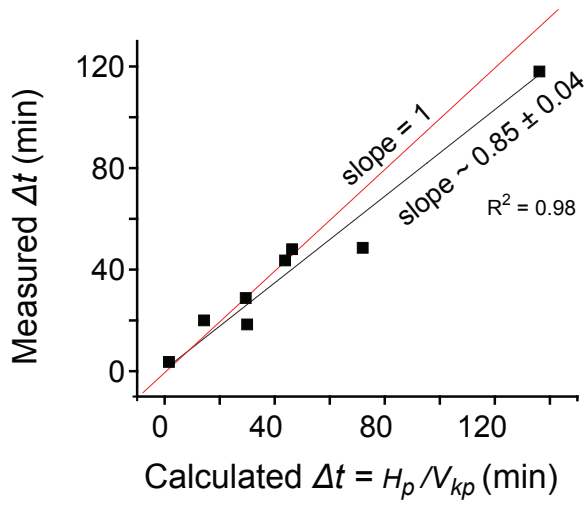

Figure 9. Comparison of the measured period between knickpoints $(\Delta t)$ to the calculated period between knickpoints using Eq. (4). Linear fit of the data is shown in black.

and a dimensionless spacing is obtained when divided by the flow depth.

$\Delta x^{*}=\frac{H_{\mathrm{p}}}{U \cdot h} V_{\mathrm{kp}}$

These equations can be derived to simulate knickpoint generation and retreat using a rule-based model (Fig. 10). The upstream distance and elevation of the $n$th knickpoint, with migration velocity $V_{\mathrm{kp}}$ are then respectively

$x_{n}=V_{\mathrm{kp}} \cdot[t-(n-1) \cdot \Delta t]$,

$y_{n}=-H_{\mathrm{p}}(n-1) \cdot \Delta t$.

In all simulations with a constant lithology, the upstream distance of the first knickpoint is similar, independent of the base-level fall rate (Fig. 10). Hence, rather than giving information about base-level fall rate, the position of this knickpoint allows assessment of the incipiency of base-level fall within the model. In the field, this would correspond to when the base-level fall or uplift had first exceeded the thickness of alluvium within the channel.

Equation (6) and Fig. 10 also show that an increase in base-level fall rate leads to the creation of more knickpoints and that the spacing between knickpoints, $\Delta x$, is inversely proportional to base-level fall rate (e.g., Fig. 10; Eq. 4). Equation (6) therefore provides an alternative relationship for interpreting uplift or base-level fall rate from knickpoint distribution/spacing on the field. Knickpoint size (e.g., plunge pool depth) is the other critical parameter of this equation; it is strongly dependent on water discharge and substrate strength. In environments with poorly consolidated material, i.e., alluvial rivers, where substrate is strengthened only by a weak compaction or vegetation, base-level falls are quickly compensated for by the migration of close, shallow knickpoints (e.g., right side of Fig. 10). In the case of bedrock rivers (e.g., left side of Fig. 10), where the substrate is more resistant and more widely spaced, deeper knickpoints are observed indicating that the response timescale of the sediment 


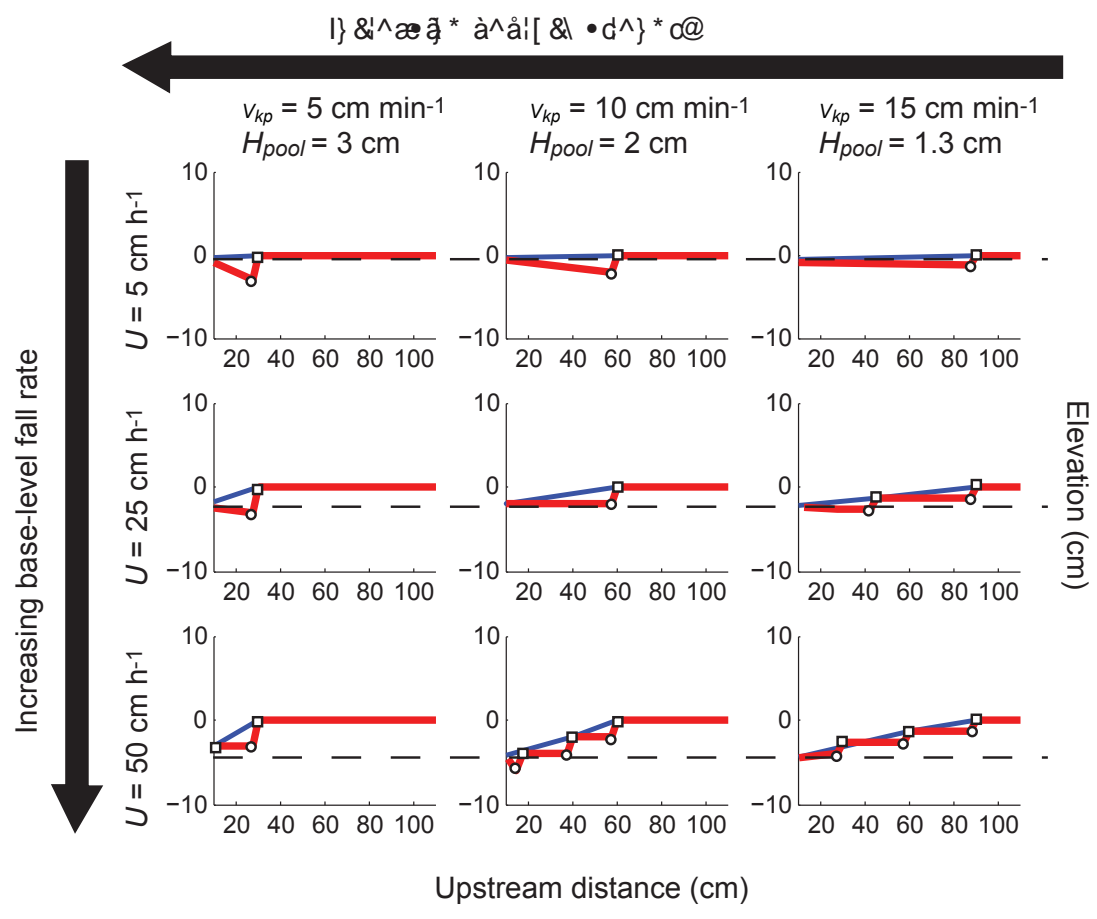

Figure 10. Snapshots of knickpoint migration calculated using Eqs. (4), (7) and (8). Each snapshot represents a simulation with a different set of parameters $\left(U, V_{\mathrm{kp}}, H_{\mathrm{p}}\right)$ stopped after $6 \mathrm{~min}$ of runtime. The bedrock surface (red line) is simulated by tracking the positions of the knickpoint (white squares) and the bottom of their associated plunge pool (white circles). The alluvium surface (blue line) is shown for comparison with the experiments. The bedrock surface initial elevation is set to zero. The first knickpoint is assumed to retreat instantaneously at a velocity $V_{\mathrm{kp}}$. The base-level falls at a rate $U$. A new knickpoint is generated each time the base level (shown by the black dashed line) reaches the depth of the plunge pool $\left(H_{\mathrm{p}}\right)$ associated with the previous retreating knickpoint. For the sake of simplicity, no diffusive processes are considered in the simulations. The water discharge and horizontal distance between knickpoints and their plunge pool bottom $(2 \mathrm{~cm})$ are assumed constant, while the velocity and height of unit knickpoints vary according to the main trend observed in the experiments (Table 1). The simulations are varying vertically as a function of base-level fall rate and horizontally as a function of substrate strength. This controls two parameters: when it is high, $V_{\mathrm{kp}}$ is low and $H_{\mathrm{p}}$ is deep, while when it is low, $V_{\mathrm{kp}}$ is high and $H_{\mathrm{p}}$ is shallower (Table 1 ).

routing system is increasingly longer. Interestingly, this behavior is the opposite of the one predicted by the analysis of Whipple (2001) that the advection response time (i.e., the time for a knickpoint to pass through a river system) is longer for alluvial (low-slope) rivers than for steeper bedrock rivers. To the extent that low-slope rivers are associated with weaker substrates, these strength variations act oppositely to the effect of slope on knickpoint propagation. At this point, without further information, the overall outcome of this competition cannot be determined.

Overall the experimental results suggest promising approaches for analyzing knickpoint dynamics as well as their spatial distribution in landscapes in relation to relative baselevel fall. Figure 11 exemplifies how bedrock lithology affects knickpoint distribution on the field based on two neighboring watersheds of similar size $\left(25 \pm 2 \mathrm{~km}^{2}\right)$ near Duluth, Minnesota. In both watersheds, base-level history is controlled by the evolution of the level of Lake Superior during glaciation-deglaciation cycles (Wright, 1973). The major difference between the two watersheds is their bedrock lithology (Fig 11a; Fitzpatrick et al., 2006). While the stream flowing above a loose sedimentary bedrock shows a small knickpoint located $10 \mathrm{~km}$ upstream (Fig. 11b), the stream flowing over a resistant gabbroic bedrock displays a big knickpoint located closer to the watershed outlet $(4 \mathrm{~km}$; Fig. 11c). These first-order observations are consistent with our experimental results that the increasing rock strength is favorable to the creation of bigger knickpoints whose upstream propagation is slower.

\subsection{Knickpoints and waterfalls: erosion processes}

Our experiments highlight the effects of sediment transport and lithology on knickpoint dynamics; a remaining challenge is to effectively link these laboratory observations to theoretical, empirical and field data. To achieve this, the mechanics and process of erosion in play must be understood and characterized. In our experiment, two erosion regimes can be observed: a background/“clear water" regime where erosion of the bed is triggered by sediment abrasion through saltation (e.g., erosion rate $\sim 0.2 \mathrm{~mm} \mathrm{~min}^{-1}$; Sklar and Dietrich, 2004; Fig. 4 c) and (ii) a waterfall regime where measured erosion 

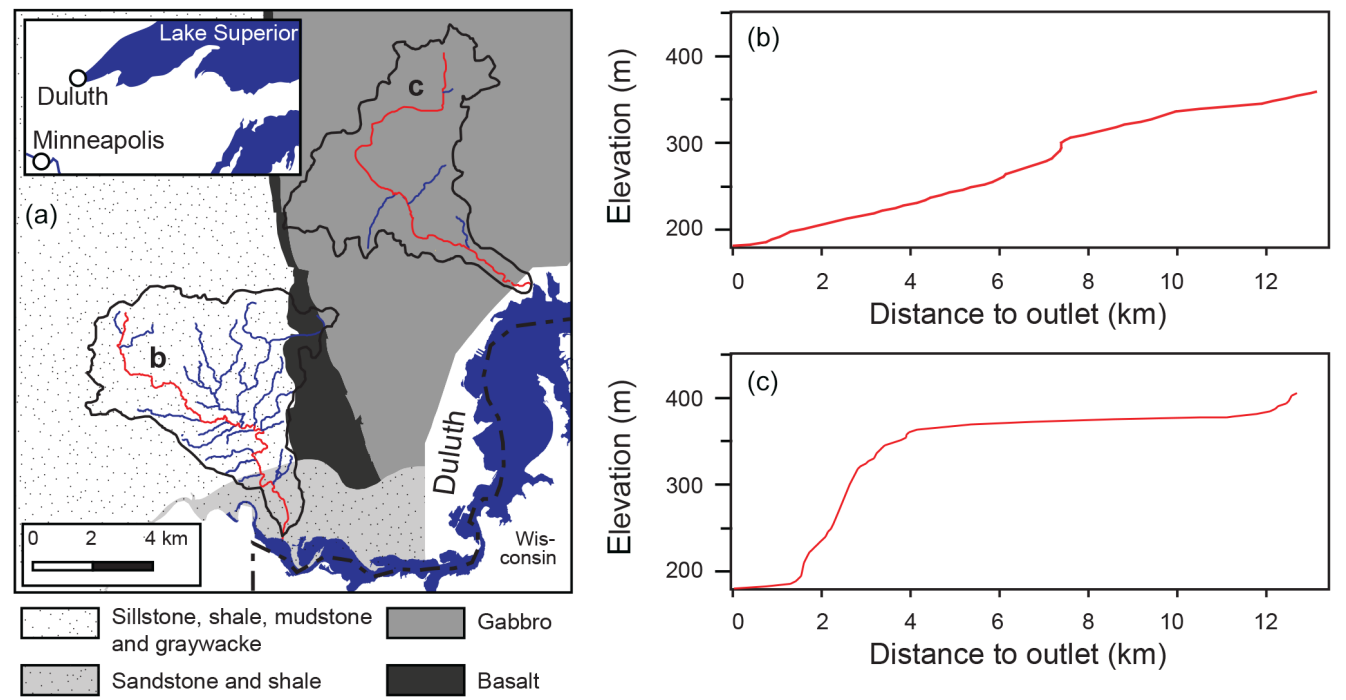

Figure 11. Morpho-geologic map showing two tributaries of the St. Louis River, close to Lake Superior shore, Duluth, Minnesota (a), and their associated long profiles: the Mission Creek (b) and Kingsbury Creek (c) rivers. Note that while the Kingsbury Creek watershed substrate is resistant gabbro, the substrate of the Mission Creek watershed is composed of loose sedimentary rocks (mainly sillstone, shale, mudstone and sandstone). The white area represents unmapped bedrock, the black line the watershed limit and the dashed line the Minnesota-Wisconsin border. Rivers are in blue. After Fitzpatrick et al. (2006). Vertical exaggeration is 20.

rate is 10 times higher $\left(\sim 1.5 \mathrm{~mm} \mathrm{~min}^{-1}\right.$; Fig. 4 a and d). The turbidity observed within the plunge pool suggests that most sediments may be in suspension there, uncovering the bottom of the pool (Lamb et al., 2007) and perhaps providing abrasive tools for erosion. The steep knickpoint face is furthermore conducive to erosion rates higher than the background rate. A more accurate quantification of erosion through abrasion would, however, require detailed tracking of sediment and flow dynamics than we were able to do, particularly to identify what fraction of the sediment is transported in suspension as opposed to bedload. Our observations are indeed limited by the size of the experiment, but detailed study using advanced particle- and flow-tracking techniques such as laser holography (Toloui and Hong, 2015) in a larger facility would be a logical next step in this line of research.

Finally, we observe undercutting and collapse of the knickpoint face in the case of more resistant bedrock (2$5 \%$ kaolinite), similar to natural examples (Seidl et al., 1994; Lamb et al., 2007). In this case, we hypothesize that sediment-laden flows in the pool are able to erode backward compared to the overall flow sense due to vorticity in the pool and, potentially, the angle of incidence of the flow, which is set by the knickpoint slope. The conditions necessary for undercutting would be worth investigation in the future, for example combining physical experiments and high-resolution numerical simulations of flow and sediment transport.

\section{Conclusion}

Based on experimental study of the influence on knickpoint retreat of base-level fall, substrate strength and transient deposits along streams using a simple 1-D flume, we find the following:

1. Rather than being tied directly to the rate and rate distribution of base-level fall, knickpoint generation is strongly modulated by autogenic (self-organized) dynamics, consistent with other recent studies.

2. Under a constant rate of base-level fall, knickpoints of similar shape (unit knickpoints) are periodically generated. Temporary shielding of the bed by alluvium controls the spacing between these knickpoints. This shielding is, however, not efficient when base-level drops exceed alluvium thickness.

3. While the base-level fall rate controls the overall slope of experiments, it is not instrumental in dictating the major characteristics of unit knickpoints. Instead, knickpoint velocity, knickpoint face slope and associated plunge pool depth are all strongly influenced by lithology.

4. The period between knickpoints is controlled by both the alluvium thickness and the base-level fall rate that dictates how fast the alluvium is removed. 
Author contributions. J.-L. Grimaud built the knickpoint flume and carried out the experiments under the supervision of C. Paola. J.-L. Grimaud developed the numerical modeling with advice from V. Voller. J.-L. Grimaud wrote the manuscript with input and corrections from C. Paola and V. Voller.

Acknowledgements. We thank Ben Erickson and Richard Christopher for their help during the flume building. We are also indebted to Alejandro Tejedor, Gary Parker, Leslie Hasbargen, Antoinette Abeyta, Aaron Buffe and Arvind Singh for fruitful discussions and suggestions, as well as to Jens Turowski and an anonymous reviewer for their input to the current version of the paper. The work was supported in part by the SAFL Industrial Consortium for Experimental Stratigraphy and the BanglaPIRE project, NSF Partnerships for International Research and Education grant IIA 09-68354.

Edited by: J. Braun

\section{References}

Allen, P. A.: Time scales of tectonic landscapes and their sediment routing systems, in: Earth's Dynamic Surface: Catastrophe and Continuity in Landscape Evolution, edited by: Gallagher, K., Jones, S. J., and Wainwright, J., Special Publication Geological Society London, 7-28, 2008.

Begin, Z. E. B., Meyer, D. F., and Schumm, S. A.: Development of longitudinal profiles of alluvial channels in response to baselevel lowering, Earth Surf. Proc. Land., 6, 49-68, 1981.

Bennett, S. J., Alonso, C. V., Prasad, S. N., and Römkens, M. J. M.: Experiments on headcut growth and migration in concentrated flows typical of upland areas, Water Resour. Res., 36, 19111922, 2000.

Bishop, P.: Long-term landscape evolution: linking tectonics and surface processes, Earth Surf. Proc. Land., 32, 329-365, 2007.

Bishop, P., Young, R. W., and McDougall, I.: Stream Profile Change and Longterm Landscape Evolution: Early Miocene and Modern Rivers of the East Australian Highland Crest, Central New South Wales, Australia, J. Geol., 93, 455-474, 1985.

Bishop, P., Hoey, T. B., Jansen, J. D., and Artza, I. L.: Knickpoint recession rate and catchment area: the case of uplifted rivers in Eastern Scotland, Earth Surf. Proc. Land., 30, 767-778, 2005.

Bonnet, S. and Crave, A.: Landscape response to climate change: Insights from experimental modeling and implications for tectonic versus climatic uplift of topography, Geology, 31, 123-126, doi:10.1130/0091-7613(2003)031<0123:Irtcci>2.0.co;2, 2003.

Bressan, F., Papanicolaou, A. N., and Abban, B.: A model for knickpoint migration in first- and second-order streams, Geophys. Res. Lett., 41, 4987-4996, doi:10.1002/2014GL060823, 2014.

Brush, L. M. and Wolman, M. G.: Knickpoint behavior in noncohesive material: a laboratory study, Geol. Soc. Am. Bull., 71, 5974, doi:10.1130/0016-7606(1960)71[59:kbinma]2.0.co;2, 1960.

Cantelli, A. and Muto, T.: Multiple knickpoints in an alluvial river generated by a single instantaneous drop in base level: experimental investigation, Earth Surf. Dynam., 2, 271-278, 2014.

Cook, K. L., Turowski, J. M., and Hovius, N.: A demonstration of the importance of bedload transport for fluvial bedrock erosion and knickpoint propagation, Earth Surf. Proc. Land., 38, 683695, 2013.

Crosby, B. T. and Whipple, K. X.: Knickpoint initiation and distribution within fluvial networks: 236 waterfalls in the Waipaoa River, North Island, New Zealand, Geomorphology, 82, 16-38, doi:10.1016/j.geomorph.2005.08.023, 2006.

Fitzpatrick, F. A., Peppler, M. C., DePhilip, M. M., and Lee, K. E.: Geomorphic Characteristics and Classification of Duluth-Area Streams, Minnesota, US Geological Survey Sci. Invest. Rep., available at: http://pubs.usgs.gov/sir/2006/5029/ (last access: 21 December 2015), 5029, 62 pp., 2006.

Frankel, K. L., Pazzaglia, F. J., and Vaughn, J. D.: Knickpoint evolution in a vertically bedded substrate, upstream-dipping terraces, and Atlantic slope bedrock channels, Geol. Soc. Am. Bull., 119, 476-486, doi:10.1130/b25965.1, 2007.

Gardner, T. W.: Experimental study of knickpoint and longitudinal profile evolution in cohesive, homogeneous material, Geol. Soc. Am. Bull., 94, 664-672, doi:10.1130/00167606(1983)94<664:esokal>2.0.co;2, 1983.

Gasparini, N. M., Bras, R. L., and Whipple, K. X.: Numerical modeling of non-steady-state river profile evolution using a sedimentflux-dependent incision model, in: Tectonics, climate and landscape evolution, edited by: Willett, S., Hovius, N., Brandon, M., and Fisher, D., GSA Special Paper, Geological Society of America, 127-141, 2006.

Grimaud, J.-L., Chardon, D., and Beauvais, A.: Very long-term incision dynamics of big rivers, Earth Planet. Sci. Lett., 405, 74-84, 2014.

Hack, J. T.: Studies of longitudinal stream profiles in Virginia and Maryland, U.S. Geol. Surv., 294-B, 45-97, 1957.

Hasbargen, L. E. and Paola, C.: Landscape instability in an experimental drainage basin, Geology, 28, 1067-1070, doi:10.1130/0091-7613(2000)28<1067:liiaed>2.0.co;2, 2000.

Holland, W. N. and Pickup, G.: Flume study of knickpoint development in stratified sediment, Geol. Soc. Am. Bull., 87, 76-82, doi:10.1130/0016-7606(1976)87< 76:fsokdi>2.0.co;2, 1976.

Hovius, N.: Regular spacing of drainage outlets from linear mountain belts, Basin Res., 8, 29-44, 1996.

Howard, A. D. and Kerby, G.: Channel changes in badlands, Geol. Soc. Am. Bull., 94, 739-752, doi:10.1130/00167606(1983)94<739:ccib>2.0.co;2, 1983.

Jerolmack, D. J. and Paola, C.: Shredding of environmental signals by sediment transport, Geophys. Res. Lett., 37, L19401, doi:10.1029/2010g1044638, 2010.

Julien, P. Y.: Erosion and Sedimentation, Cambridge University Press, 280 pp., 1998.

$\mathrm{Ku}, \mathrm{H}$. H.: Notes on the use of propagation of error formulas, J. Res. Natl. Bur. Stand., 70C, 263-273, doi:10.6028/jres.070c.025, 1966.

Lamb, M. P., Howard, A. D., Dietrich, W. E., and Perron, J. T.: Formation of amphitheater-headed valleys by waterfall erosion after large-scale slumping on Hawai'i, Geol. Soc. Am. Bull, 119, 805-822, doi:10.1130/b25986.1, 2007.

Loget, N., Davy, P., and Van Den Driessche, J. C. F.: Mesoscale fluvial erosion parameters deduced from modeling the Mediterranean sea level drop during the Messinian (late Miocene), J. Geophys. Res.-Earth, 111, F03005, doi:10.1029/2005JF000387, 2006. 
Métivier, F. and Gaudemer, Y.: Stability of output fluxes of large rivers in South and East Asia during the last 2 million years: implications on floodplain processes, Basin Res., 11, 293-303, doi:10.1046/j.1365-2117.1999.00101.x, 1999.

Miller, J. R.: The Influence of Bedrock Geology on Knickpoint Development and Channel-Bed Degradation along Downcutting Streams in South-Central Indiana, J. Geol., 99, 591-605, 1991.

Mitchener, H. and Torfs, H.: Erosion of mud/sand mixtures, Coastal Eng., 29, 1-25, 1996.

Paola, C., Straub, K., Mohrig, D., and Reinhardt, L.: The "unreasonable effectiveness" of stratigraphic and geomorphic experiments, Earth-Sci. Rev., 97, 1-43, 2009.

Parker, R. S.: Experimental Study of Drainage Basin Evolution and Its Hydrologic Implications, Hydrology papers, Colorado State University, Fort Collins, 85 pp., 1977.

Parker, G.: Some speculations on the relation between channel morphology and channel-scale flow structures, in: Coherent Flow in Open Channels., edited by: Ashworth, P., Bennet, S., Best, J. L., and McLelland, S., John Wiley \& Sons, New York, 429-432, 1996.

Pederson, J. L. and Tressler, C.: Colorado River long-profile metrics, knickzones and their meaning, Earth Planet. Sc. Lett., 345348, 171-179, doi:10.1016/j.epsl.2012.06.047, 2012.

Rosenbloom, N. A. and Anderson, R. S.: Hillslope and channel evolution in a marine terraced landscape, Santa Cruz, California, J. Geophys. Res.-Sol. Ea., 99, 14013-14029, 1994.

Seidl, M. A., Dietrich, W. E., and Kirchner, J. W.: Longitudinal Profile Development into Bedrock: An Analysis of Hawaiian Channels, J. Geol., 102, 457-474, 1994.

Sklar, L. S. and Dietrich, W. E.: Sediment and rock strength controls on river incision into bedrock, Geology, 29, 1087-1090, 10.1130/0091-7613(2001)029<1087:sarsco>2.0.co;2, 2001.
Sklar, L. S. and Dietrich, W. E.: A mechanistic model for river incision into bedrock by saltating bed load, Water Resour. Res., 40, W06301, doi:10.1029/2003WR002496, 2004.

Snyder, N. P.: Channel response to tectonic forcing; field analysis of stream morphology and hydrology in the Mendocino triple junction region, Northern California, Geomorphology, 53, 97127, 2003.

Stein, O. and Julien, P.: Criterion Delineating the Mode of Headcut Migration, J. Hydraul. Eng., 119, 37-50, doi:10.1061/(ASCE)0733-9429(1993)119:1(37), 1993.

Toloui, M. and Hong, J.: High fidelity digital inline holographic method for 3D flow measurements, Opt. Express, 23, 2715927173, 2015.

van der Beek, P. and Bishop, P.: Cenozoic river profile development in the Upper Lachlan catchment (SE Australia) as a test of quantitative fluvial incision models, J. Geophys. Res., 108, 2309, doi:10.1029/2002jb002125, 2003.

Whipple, K. X. and Tucker, G. E.: Dynamics of the stream-power river incision model; implications for height limits of mountain ranges, landscape response timescales, and research needs, J. Geophys. Res., 104, 17661-17674, 1999.

Whipple, K. X.: Fluvial Landscape Response Time: How Plausible Is Steady-State Denudation?, Am. J. Sci., 301, 313-325, doi:10.2475/ajs.301.4-5.313, 2001.

Whipple, K. X.: Bedrock rivers and the geomorphology of active orogens, Annu. Rev. Earth and Planet. Sci., 32, 151-185, 2004.

Wilson, J. W. P., Roberts, G. G., Hoggard, M. J., and White, N. J.: Cenozoic epeirogeny of the Arabian Peninsula from drainage modeling, Geochem., Geophys., Geosyst., 15, 3723-3761, 2014.

Wright, H. E.: Tunnel Valleys, Glacial Surges, and Subglacial Hydrology of the Superior Lobe, Minnesota, Geol. Soc. Am. Mem. 136, 251-276, doi:10.1130/MEM136-p251, 1973. 